\title{
Physiochemical and Biological Properties of Water of Khyber Paktun Khwa District Bannu, Pakistan 2014
}

\author{
Waqas Ahmad Shams ${ }^{1,}$, Unays Siraj ${ }^{1}$, Gauhar Rehman ${ }^{1}$, Zahid Ullah $^{2}$, Naveed Ahmad ${ }^{1}$, \\ Maaz Miraj ${ }^{1}$, Asad Ullah ${ }^{1}$, Sadaf Niaz ${ }^{1}$, Khurshaid Khan ${ }^{1}$, Huma Alam ${ }^{1}$, Nida Gul ${ }^{1}$, Tahira Naz ${ }^{1}$, \\ Saif ul Islam ${ }^{3}$, Abdul Jamil Khan ${ }^{1}$ \\ ${ }^{1}$ Department of Zoology, Abdul Wali Khan University Mardan, Mardan, Pakistan \\ ${ }^{2}$ Department of Zoology, University of Buner, Buner, Pakistan \\ ${ }^{3}$ Department of Zoology, Government Degree College Lahor, Swabi, Pakistan
}

Email address:

Wshams89@awkum.edu.pk (W. A. Shams)

${ }^{*}$ Corresponding author

\section{To cite this article:}

Waqas Ahmad Shams, Unays Siraj, Gauhar Rehman, Zahid Ullah, Naveed Ahmad, Maaz Miraj, Asad Ullah, Sadaf Niaz, Khursheed Khan, Huma Alam, Nida Gul, Tahira Naz, Saif ul Islam, Abdul Jamil Khan. Physiochemical and Biological Properties of Water of Khyber Paktun Khwa District Bannu, Pakistan 2014. International Journal of Photochemistry and Photobiology. Vol. 2, No. 1, 2018, pp. 12-15.

doi: $10.11648 /$ j.jpp. 20180201.13

Received: July 18, 2018; Accepted: August 8, 2018; Published: September 5, 2018

\begin{abstract}
In developing countries, Arsenic concentrations overhead satisfactory values for drinking water have been identified in many countries and this should, therefore, it is a global concern. The presence of arsenic in subsurface aquifers and drinking water systems is a possibly serious social health hazard. The existing population growth in Pakistan and other developing countries will have a straight bearing on the water zone for meeting the domestic, industrial and agricultural needs. Pakistan is about to exhaust its accessible water resources and is on the verge of becoming a water deficit country. Water contamination is a serious threat in Pakistan, as almost $70 \%$ of its surface waters, as well as its groundwater reserves, have contaminated by biological, organic and inorganic pollutants. In some areas of Pakistan, a number of shallow aquifers and tube wells are contaminated with arsenic at levels which are above the recommended USEPA arsenic level of $10 \mathrm{ppb}(10 \mathrm{~g} \mathrm{~L}-1)$. Opposing health effects including human mortality from drinking water are well documented and can be attributed to arsenic contamination. All of the areas of Bannu district was studied. The present paper reviews appropriate and low-cost methods for the elimination of arsenic from drinking waters.
\end{abstract}

Keywords: PH, Turbidity, Total Dissolved Solid, Electric Conductivity, E. coli, Arsenic

\section{Introduction}

More than $70 \%$ of the Earth's surface covers by water, but freshwater less than $3 \%$ of this. But only $0.01 \%$ amount of fresh water is available for human consumption while the remaining is bound in glaciers and ice [1]. The total water of this small proportion of the Earth's is becoming polluted to various harmful components due to the large disposal of industrial and municipal wastes and large scales applications of the chemical in agriculture. Anthropogenic activities introduce various hazardous and harmful substance to the water which results in widespread water linked diseases [2]. Poor water quality is main environmental and health-related concern in Pakistan. Both groundwater and surface in the country are polluted with various toxic component and microorganisms [3]. Within the last years it has become increasingly plain to most of us that the sufficiency of freshwater supplies is a significant problem not only in arid regions. It proves an apparent negative impact of climate change as a variability in precipitation amount and distribution together with rising temperatures. According to last "Statement on the State of the Global Climate" issued every year by the World Meteorological Organization [4], the year 2016 was the warmest year on record: a remarkable $1.1^{\circ} \mathrm{C}$ above the pre-industrial period, which is at the same time $0.06^{\circ} \mathrm{C}$ above the previous record set in 2015. As a consequence, water scarcity and droughts are more and more frequent and already widespread across Europe. How the 
European Environment Agency refers, at least 11\% of the population and $17 \%$ of the European territory have been struck by water scarcity [5]. It concerns not only the southern parts of Europe, but also other parts of Europe, where water deficiency may occur

In the country, bad living and natural disasters coupled with mismanagement frequently contaminate drinking water [4]. Current water supply coverage of $79 \%$ to Pakistan's population [5]. The quality of surface water is deteriorating as a result of the disposal of untreated municipal and industrial wastewaters and saline drainage effluent from agricultural areas [6]. Warm-blooded organism excreta contain faecal coliform and other bacteria. Each calendar day per capita excreta of faecal coliform and other bacteria ranges from 100 to 400 billion [7].

Due to contamination of drinking water, people repeatedly suffer from waterborne diseases. Almost 30\% of all reported diseases and $40 \%$ of all deaths in the country are attributed to faecal contamination of drinking waters [8]. A recent study conducted in the Bannu City of Khyber Pakhtunkhwa attributed faecal contamination of drinking water to old rusted pipes, water distribution pipes lying on the bank of or inside sewers, unburied water supply pipes lying on roadsides, and water supply networks submerged in sewerages [9].

\section{Method and Materials}

ACF team visited Field to assess the existing drinking water sources/types interims of quality and quantity. During the assessment of water sources, different tools were used to measure water quality parameters of existing sources to capture the current water quality conditions of existing sources both at the household level as well as communal level. The prime purpose of this activity was to evaluate the drinking water quality in the targeted area of KP-VI.

\subsection{Water Sampling Methodology}

ACF team conducted FGDs to capture information about the current drinking water sources (types, quality and quantity). Along with FGD, ACF team conducted transit walks to cross verify the information and to observe the current status of drinking water sources and current practices of water collection of the target community. During transit walk, random samples were collected from all the available types of sources of targeted communities to observe water quality parameters.

\subsection{Water Quality Analysis}

Random samples were collected in 70 villages of targeted 5 Union Councils UCs of district Bannu, from all the available types of sources to observe different physical, chemical and bacteriological parameters.

Different physical water quality parameters were observed and also Digital meter was used for field level to test like the smell, colour, taste, $\mathrm{pH}$, Turbidity, Total Dissolved Solids (TDS) and Electric Conductivity (EC). Bacteriological tests (E-coli) and Chemical test (Arsenic) were conducted in ACF laboratory by using DelAgua testing kit and Quantofix arsenic kits. As per field findings, the following water sources exist in the area of intervention; Motorized borehole, PHED Schemes, Open well, shallow hand pumps and borehole with Natural water flow

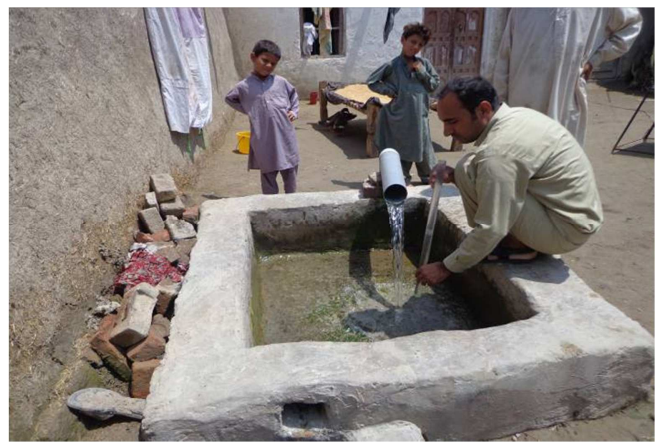

Figure 1. Water pump in open area.

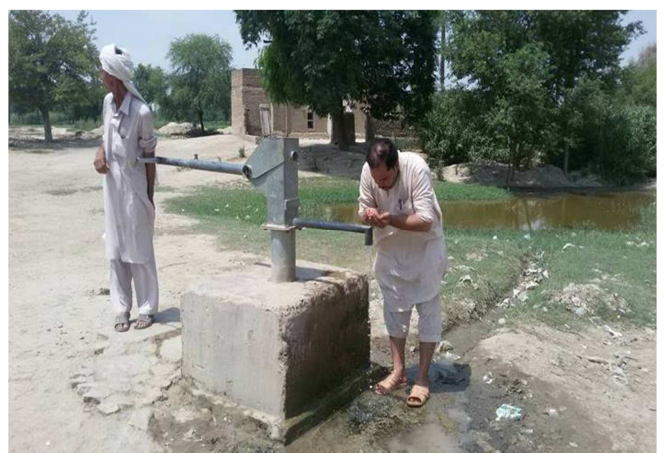

Figure 2. Water hand pump by community.

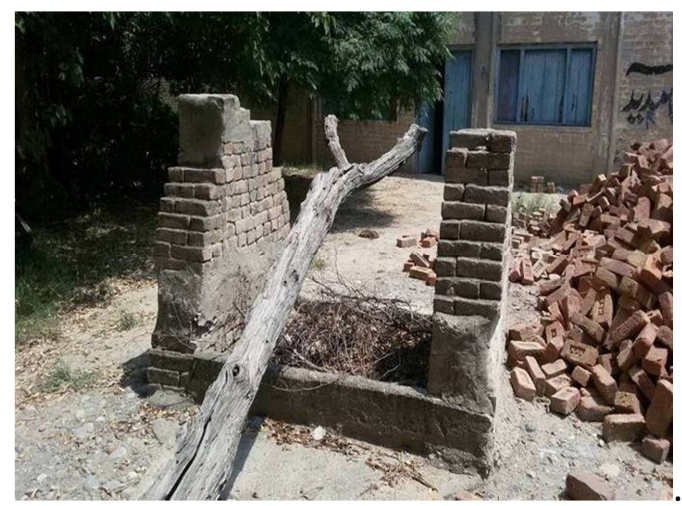

Figure 3. Non Functional Open well.

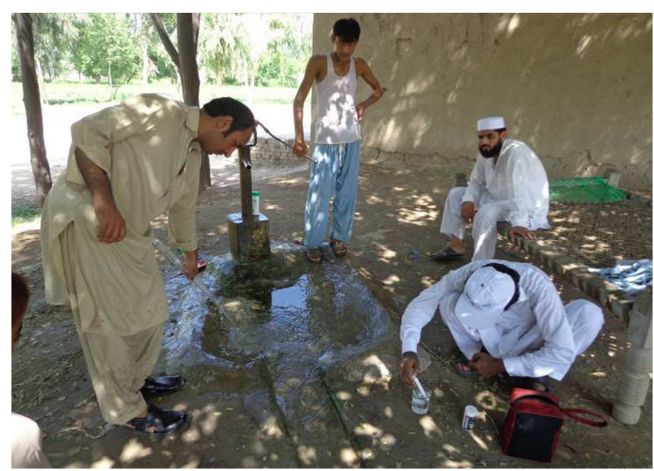

Figure 4. Communal Hand pump. 
Table 1. Report of Water quality KP-VI District Bannu, Pakistan 2014.

\begin{tabular}{|c|c|c|c|c|c|c|c|c|c|c|c|}
\hline \multirow{3}{*}{$\begin{array}{l}\text { Factors } \\
\text { Turbidity }\end{array}$} & \multirow{2}{*}{$\begin{array}{c}\text { Variables } \\
\text { Permissible limit }(<5)\end{array}$} & \multicolumn{2}{|c|}{$\begin{array}{l}\text { UC Shebaz } \\
\text { Azmat Khel }\end{array}$} & \multicolumn{2}{|c|}{ UC Bakakahil } & \multicolumn{2}{|c|}{ UC Baharat } & \multicolumn{2}{|c|}{$\begin{array}{l}\text { UC Kot } \\
\text { Qalander }\end{array}$} & \multicolumn{2}{|c|}{$\begin{array}{l}\text { UC Mumbati } \\
\text { Barakzai }\end{array}$} \\
\hline & & 21 & $64 \%$ & 4 & $36 \%$ & 18 & $49 \%$ & 21 & $16 \%$ & 16 & $94 \%$ \\
\hline & Above permissible limit & 12 & $36 \%$ & 7 & $64 \%$ & 19 & $51 \%$ & 4 & $84 \%$ & 1 & $6 \%$ \\
\hline \multirow{2}{*}{ PH } & Permissible limit (6.5-8.5) & 33 & $100 \%$ & 11 & $100 \%$ & 37 & $100 \%$ & 20 & $80 \%$ & 14 & $82 \%$ \\
\hline & Above permissible limit & 0 & $0 \%$ & 0 & $0 \%$ & 0 & $0 \%$ & 5 & $20 \%$ & 3 & $18 \%$ \\
\hline \multirow{3}{*}{$\begin{array}{l}\text { Escherichia coli } \\
(E \text {-coli })\end{array}$} & Permissible limit $(0 \mathrm{Col} / 100 \mathrm{ml})$ & 7 & $21 \%$ & 3 & $27 \%$ & 5 & $13 \%$ & 1 & $4 \%$ & 6 & $35 \%$ \\
\hline & Above permissible limit & 21 & $64 \%$ & 8 & $73 \%$ & 24 & $65 \%$ & 24 & $96 \%$ & 10 & $59 \%$ \\
\hline & Not Applicable due to turbidity & 5 & $15 \%$ & 0 & $0 \%$ & 8 & $22 \%$ & 0 & - & 1 & $6 \%$ \\
\hline \multirow{2}{*}{ Arsenic } & Permissible Limit & 33 & $100 \%$ & 11 & $100 \%$ & 37 & $100 \%$ & 25 & $100 \%$ & 17 & $100 \%$ \\
\hline & Above permissible limit & 0 & $0 \%$ & 0 & $0 \%$ & 0 & $0 \%$ & 0 & $0 \%$ & 0 & $0 \%$ \\
\hline Total Dissolved & Permissible limit $(<1000 \mathrm{ppm})$ & 33 & $100 \%$ & 11 & $100 \%$ & 33 & $89 \%$ & 20 & $20 \%$ & 17 & $100 \%$ \\
\hline Solids (TDS) & Above permissible limit & 0 & $0 \%$ & 0 & $0 \%$ & 4 & $11 \%$ & 5 & $80 \%$ & 0 & $0 \%$ \\
\hline Electric & Permissible limit (<1500 Micro. S/cm) & 33 & $100 \%$ & 11 & $100 \%$ & 29 & - & 20 & $100 \%$ & 12 & - \\
\hline Conductivity (EC) & Above Permissible limit & 0 & $0 \%$ & 0 & $0 \%$ & 8 & - & 0 & $0 \%$ & 5 & - \\
\hline
\end{tabular}

\section{Results}

The results of each targeted union council are as follows.

\subsection{Union Council Shebaz, Azmat Khel}

Total 33 sources were collected from UC Shebaz Azmat Khel. The taste odour and colour of 28 sample collected were in range only 5 sample are not eligible due to turbidity range more than 30 NTU. The electrical conductivity of 28 sample is in range and 5 sources sample was not found in range.

Similarly, the $\mathrm{pH}$ and conductivity of all sample are in the normal range. The turbidity of 21 sample is found in range while 12 sample has above permissible range (more than 5 NTU) the water from all sources is safe from arsenic. The E.coli of 7 sources is suitable for drinking while 21 sources are above permissible range and 5 sources are not applicable due to high range of turbidity.

\subsection{Union Council Bakakahil}

11 locations were checked from a different type of drinking water sources used in union council i.e. motorized bore, open well, and irrigation tube well. The order, colour, taste, TDS, EC and arsenic of samples observed are found satisfactory. While out of 11 tested sample 4 sources were under the permissible limit and seven sources are above permissible range. The E.coli of 8 sources is found contaminated and three are suitable for drinking purpose.

\subsection{Union Council Baharat}

37 locations were being targeted. The colour, odour and taste of 29 locations are satisfactory and 8 are found with turbidity level (more than $30 \mathrm{NTU}$ ) which mean that these 8 sources are not applicable for this parameter. The $\mathrm{pH}$ and arsenic of all 37 sources are within the range.

The TDS of 33 sources is within the permissible range and 4 sources are above the range. The turbidity of 18 is normal and 19 sources are turbid. The EC of 29 is normal and 8 is above the permissible range. The E.coli of 5 is normal while 24 and not suitable for drinking and 8 sources are not applicable for the test due to turbidity (more than 32 NTU).

\subsection{Union Council Kot Qalander}

The order, colour, taste and arsenic of 25 selected samples are normal. The pH, EC and TDS of 20 out of 25 sources are normal and 5 remaining are above the recommended range. The turbidity of 21 sources is normal and 4 sources are turbid. The E.coli of one source is normal and 24 are contaminated as per results.

\subsection{Union Council Mumbai Barakzai}

As per 17 location samples, the odour, taste and colour of 16 are in normal range only one source was not applicable due to high turbidity level. The turbidity level of 16 is normal and one source is found turbid. The TDS and Arsenic results are normal. The EC of 12 sources is within range and 5 are above $1500 \mu \mathrm{S} / \mathrm{cm}$. The E.coli of 6 sources is normal and 10 are above the found with faecal contamination and one is not applicable for E.coli test due to high turbidity.

\subsection{Turbidity}

The highest turbidity level of $94 \%$ is observed in Union council Mumbati Barakzai. The results show 65\% average turbidity of all union councils. While the average of $35 \%$ water sources is not found turbid. (Less than 5 NTU)

\subsection{E. coli (Faecal Coliform)}

As per lab Results the E.coli contamination in union council Kot Qalander is too high i.e. 96\%. The results show $72 \%$ average faecal contamination of all union councils. $9 \%$ water sources are not applicable for E.coli desired results due to high turbidity. Only $19 \%$ of water is suitable for drinking in targeted areas.

\subsection{Electrical Conductivity/Arsenic/TDS}

The results show EC and TDS ranges are although high for some sources but are not up to the risk level which can cause vulnerability. In targeted area arsenic is not deducted in any case. 


\section{Discussion}

The present study demonstrated the importance of proper management of Motorized borehole, PHED Schemes, Open well, shallow hand pumps and borehole with Natural water flow. Bacteriological quality of drinking water supplied from hand pumps and other sources. As the results shows that the highest turbidity level of $>94 \%$ is observed in Union council Mumbati Barakzai such like rise in turbidity level was also observed by Ahmed et al., 2014 for Abbottabad [1]. The presence of E-coli and other bacteria is alarming point for all peoples of area. The arsenic level was up to normal level which is good observation like Aziziullah et al., 2011 study [4]. Despite a very strong simplification of the Total Dissolved Solids and ammonia transformation process, we gained high quality results approaching the measured values. We did not consider the temperature effect since only irrigation during the vegetation seasons is assumed, where the subsoil temperatures are approximately similar as given by Kriška et al., 2018 [11]. On the other hand, the use of treated wastewater as a source of drinking water has its disadvantages, such as soil contamination by pathogenic organisms, drugs or heavy metals. Likewise, there is a danger for people working and operating with the irrigation system and using it for drinking.

\section{Conclusion}

From Physiochemical and Biological Properties of Water of Khyber Paktun Khwa District Bannu we conclude that we have bit problems in the water of this area. The drinkingwater supplies are largely contaminated and for consumers pose serious health risks. For drinking to ensure safe water supplies, there is essential to formulate an effective management strategy. Establish drinking-water quality standards and a groundwater regulatory framework, most important work to ban land disposal of wastewaters and strictly enforce national environmental quality standards. In addition, make some effective way for Initiate mapping of the rural groundwater quality and define the type of monitoring for urban and rural drinking-water quality.

\section{Recommendation}

Based on field finding the following are recommendations and suggestions. Avoid all those areas where hand pumps are not feasible especially low water table area. Rehabilitation is not possible for shallow pumps due to insufficient water column low depth, less discharge and small size borehole dia. Rehabilitation of existing sources requires drilling of the hole with 6" to 10 "dia with permanent water column (40 to 50 feet) and follow sanitary criteria, whereas existing sources lacks all the mentioned criteria and standards, the team suggested developing new sources in areas where hand pumps are cleared and cover maximum population.

\section{Acknowledgements}

The authors would like to acknowledge the ACF team and Zoology Department of Abdul Wali Khan University Mardan.

\section{References}

[1] Ahmed T, Pervez A, Mehtab M, Sherwani SK (2014) Assessment of drinking water quality and its potential health impacts in academic institutions of Abbottabad (Pakistan). Desalin Water Treat. doi:10. 1080/19443994.2014.890133.

[2] Soomro ZA, Khokhar MIA, Hussain W, Hussain M (2011) Drinking water quality challenges in Pakistan. Pakistan Council of Research in Water Resources, Lahore, pp 17-28.

[3] Metcalf and Eddy, Wastewater engineering treatment and reuse, 4th edition.

[4] WMO (2017): WMO Statement on the State of the Global Climate in 2016. Geneva, World Meteorological Organization.

[5] EEA (2012): Towards Efficient Use of Water Resources in Europe. EEA Report No. 1/2012. Copenhagen, European Environment Agency.

[6] Azizullah A, Khattak MNK, Richter P, Häder D-P (2011) Water pollution in Pakistan and its impact on public health-a review. Environ Int 37:479-497.

[7] Rasheed F, Khan A, Kazmi SU (2009) Bacteriological analysis, antimicrobial susceptibility and detection of $16 \mathrm{~S}$ rRNA gene of Helicobacter pylori by PCR in drinking water samples of earthquake affected areas and other parts of Pakistan. Mal J Microbiol 5: 123-127.

[8] Pakistan integrated household survey (PIHS). Islamabad, Federal Bureau of Statistics, Government of Pakistan, 2000].

[9] Chilton PJ et al. Pakistan water quality mapping and management project. Scoping study - draft final report. Loughborough, UK, Water, Engineering and Development Centre, Loughborough University \& London School of Hygiene \& Tropical Medicine, 2001 (WELL Task 568).

[10] Draft South Asia-water vision 2025, Country Report, Pakistan. Maharashtra, India, Global Water Partnership, South Asia Technical Advisory Committee Regional Office, 2000.

[11] Khan AU, Iqbal Q, Khan FA, Ashraf S (2013a) Impact of urbanization on potable water quality: a bacteriological case study of Bannu city. Sci Int (Lahore) 25:559-564.

[12] Kubátová E, Janeček M, Kobzová D. (2009): Time variations of rainfall erosivity factor in the Czech Republic. Soil and Water Research, 4.

[13] Kriška M., Němcová M., Hyánková E. (2018): The influence of ammonia on groundwater quality during wastewater irrigation. Soil \& Water Res., 13: 161-169. 